\title{
MENINGKATKAN PENGETAHUAN PESERTA DIDIK MENGGUNAKAN MODEL PEMBELAJARAN LEARNING CYCLE 5 FASE PADA MATERI REAKSI REDUKSI DAN OKSIDASI
}

\section{Improving Students Knowledge Use Learning Model Of The 5 Phase Learning Cycle In Oxidation and Reduction Reactions Material}

\section{Isnani Hayati*, Arif Sholahuddin, Yudha Irhasyuarna}

Program Studi Pendidikan Kimia FKIP Universitas Lambung Mangkurat, Jl. Brigjend. H. Hasan Basry Banjarmasin 70123 Kalimantan Selatan Indonesia *email: isnanihayati6@gmail.com

\begin{abstract}
Abstrak. Telah dilaksanakan penelitian tentang meningkatkan pengetahuan peserta didik pada materi reaksi reduksi dan oksidasi menggunakan model pembelajaran Learning Cycle 5 fase di kelas SMA Negeri 11 Banjarmasin tahun ajaran 2018/2019 dengan jumlah peserta didik sebanyak 35 orang yang terdiri dari 17 orang laki-laki dan 18 orang perempuan. Penelitian ini bertujuan untuk (1) meningkatkan hasil belajar kognitif peserta didik, dan (2) mengetahui respon peserta didik terhadap penerapan model pembelajaran Learning Cycle 5 Fase. Metode penelitian yang digunakan adalah penelitian tindakan kelas (PTK) dengan 2 pertemuan untuk siklus 1 dan 1 pertemuan siklus 2. Setiap siklus terdiri dari perencanaan, pelaksanaan tindakan, observasi dan evaluasi serta refleksi. Hasil penelitian menunjukkan bahwa terjadi (1) peningkatan hasil belajar pengetahuan peserta didik, dan (2) respon positif peserta didik terhadap penggunaan model pembelajaran Learning Cycle 5 fase.
\end{abstract}

Kata kunci: Learning Cycle 5 Fase, reaksi reduksi dan oksidasi

\begin{abstract}
Reseach has been carried out on improving student knowledge in reduction and oxidation reactions material through learning model of the 5phase learning cycle in class X SMA Negeri 11 Banjarmasin with 35 student consisting of 17 Men and 18 women. This study aims to improve students 'cognitive learning outcomes and find out students' responses to the application learning model of the 5-phase learning cycle. The research methode was used the classroom action research with 2 meetings for cycle 1 and 1 meeting for cycle 2. Each cycle consisted of planning, implementing actions, observing, and evaluating and reflecting. The results of this study indicated that there is an improvement in students' knowledge and studens, positive responses through learning model of the 5-phase learning cycle.
\end{abstract}

Keywords: Learning Cycle 5 Fase, reaksi reduksi dan oksidasi

\section{PENDAHULUAN}

Pelajaran kimia seringkali dianggap sulit bagi kebanyakan peserta didik karena kimia bersifat abstrak dan melibatkan perhitungan yang rumit, jadi peserta didik kurang tertarik untuk mengikuti pelajaran kimia di sekolah. Hal ini berakibat pada pencapaian hasil belajar yang cenderung masih terdapat peserta didik belum mencapai standar ketuntasan minimal (KKM).

Hasil belajar peserta didik yang rendah dapat disebabkan oleh faktor kurang antusiasnya peserta didik dalam mengikuti pembelajaran materi reaksi reduksi dan oksidasi. Hal ini terjadi karena penggunaan model dan metode yang digunakan tidak mampu menarik perhatian peserta didik untuk belajar. Berdasarkan wawancara yang

Copyright $\odot$ JCAE-Jurnal Tugas Akhir Mahasiswa, e-ISSN 2613-9782

Program Studi Pendidikan Kimia FKIP Universitas Lambung Mangkurat 
telah dilakukan dengan guru kimia kelas X di SMA Negeri 11 Banjarmasin Ibu Yuliana, S.Pd bahwa peserta didik banyak mengalami kesulitan belajar dalam materi reaksi reduksi oksidasi. Menurut beliau masih banyak peserta didik yang belum dapat mencapai standar ketuntasan minimal pada materi tersebut. Hal itu disebabkan oleh karakteristik materi yang sulit terutama pada materi penentuan bilangan oksidasi unsur dalam suatu senyawa.

Hasil wawancara tersebut diperkuat dengan persentase rata-rata peserta didik yang belum tuntas pada tahun pelajaran 2017/2018 dalam ulangan harian pada materi reaksi reduksi dan oksidasi, dari rata-rata 4 kelas X yang ada di SMA Negeri 11 Banjarmasin diperoleh sebanyak $35 \%$ peserta didik belum mencapai standar ketuntasan yaitu 70 atau secara klasikal belum tercapai $75 \%$ penguasaan materinya.

Berdasarkan faktor-faktor permasalahan yang mempengaruhi hasil belajar peserta didik yang rendah, maka perlu menerapkan model pembelajaran yang tepat untuk dapat memberikan kesempatan kepada peserta didik untuk terlibat secara aktif dalam proses belajar mengajar di kelas, sehingga diharapkan dapat meningkatkan pencapaian hasil belajarnya pada materi reaksi reduksi oksidasi ini.

Model pembelajaran yang berparadigma kontruktivistik diyakini mampu menjadikan peserta didik aktif dalam proses pembelajaran. Model pembelajaran konstruktivisme mengajak peserta didik untuk membangun pengetahuannya sendiri, sehingga peserta didik tidak mudah melupakan konsep yang sedang diperoleh dan dipelajarinya. Salah satu model pembelajaran yang berparadigma kontruktivistik adalah model pembelajaran Learning Cycle 5 fase. Model pembelajaran Learning Cycle 5 fase terdiri dari fase pendahuluan, eksplorasi, penjelasan, konsep dan evaluasi. Model pembelajaran ini menyarankan agar proses pembelajaran dapat melibatkan peserta didik dalam kegiatan belajar yang aktif. Hal ini akan berdampak pada konstruksi pengetahuan peserta didik yang baik sehingga mampu meningkatkan pemahaman peserta didik terhadap materi yang dipelajari. Model pembelajaran Learning Cycle 5 Fase ini pernah diterapkan oleh Saputri, Medriati \& Rohadi (2018), yang menunjukkan bahwa pembelajaran dengan menggunakan model Learning Cycle 5 Fase dapat meningkatkan aktivitas belajar, hasil belajar kognitif, dan keterampilan proses sains siswa. Rejeki, Hasan \& Gani (2015), yang menunjukkan bahwa pembelajaran dengan menggunakan model Learning Cycle 5 Fase dapat meningkatkan hasil belajar dan sikap peserta didik, dan penelitian dari Ikhtiarianti, Redjeki \& Mulyani (2015) penerapan model Learning Cycle 5 Fase dapat meningkatkan aktivitas dan prestasi belajar siswa.

Berdasarkan latar belakang masalah di atas maka penelitian tindakan kelas ini akan menerapkan model pembelajaran Learnig Cycle 5 Fase dalam proses pembelajaran pada materi reaksi reduksi dan oksidasi untuk meningkatkan pengetahuan peserta didik.

\section{METODE PENELITIAN}

Penelitian ini menggunakan jenis PTK. Penelitian dilaksanakan pada 9 April s.d. 9 Mei 2019 dengan objek penelitian 35 peserta didik kelas XI MIPA 2 SMA Negeri 11 Banjarmasin. Teknik pengumpulan data yang digunakan yaitu teknik tes dan non tes. Teknik tes dilakukan dengan memberikan serangkaian soal kepada peserta didik dan instrumen soal yang digunakan berbentuk objektif. Teknik non tes dilakukan dengan melaksanakan observasi dan membagi angket kepada peserta didik. Angket yang diberikan kepada peserta didik untuk mengetahui bagaimana respon peserta didik terhadap pembelajaran menggunakan model pembelajaran Learning Cycle 5 Fase. Sedangkan observasi digunakan untuk memperoleh datadata tentang kegiatan belajar guru dalam melaksanakan proses belajar mengajar. 


\section{HASIL PENELITIAN DAN PEMBAHASAN \\ Hasil Penelitian \\ Aktivitas Guru}

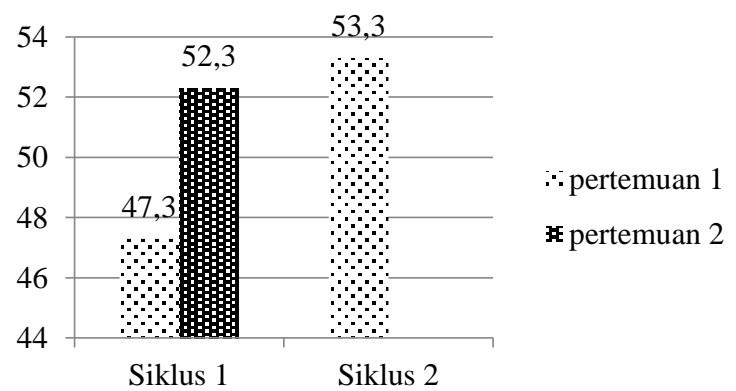

Gambar 1. Skor rata-rata aktivitas guru pada siklus 1 dan 2

Penerapan model pembelajaran Learning Cycle 5 fase ini dapat menjadikan aktivitas guru meningkat, terlihat dari hasil penilaian ketiga observer dari siklus 1 pertemuan 1 adalah 42,3 dan pertemuan 2 adalah 52,3, sedangkan pada siklus 2 hasil penilaian ketiga observer adalah 53,3. Dari keaktifan guru berperan besar dalam meningkatkan proses belajar mengajar yang berdampak pada penguasaan konsep dan hasil belajar peserta didik itu sendiri.

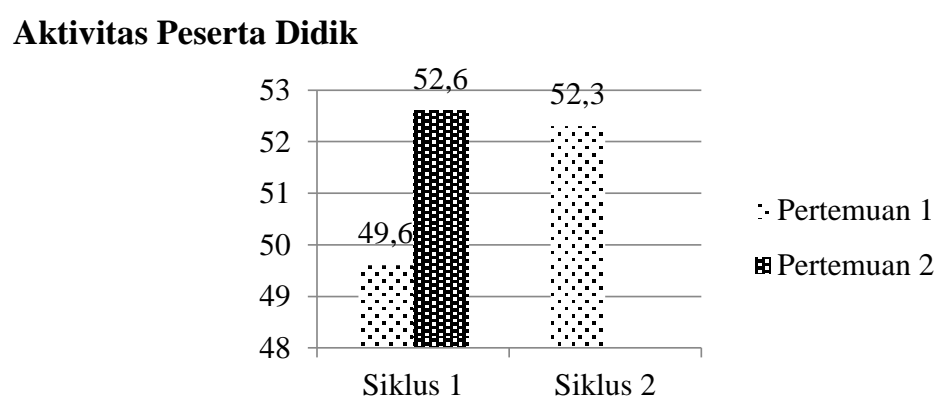

Gambar 2. Skor rata-rata aktivitas peserta didik pada siklus 1 dan 2

Penerapan model pembelajaran learning cycle 5 Fase ini dapat menjadikan peserta didik lebih aktif terlibat dalam proses pembelajaran terlihat pada aktivitas peserta didik dari siklus 1 pertemuan 1 penilaian dari ketiga observer adalah 49,6 sedangkan pertemuan 2 adalah 52,6 dan pada siklus 2 terjadi peningkatan aktivitas peserta didik sebesar 52,3. Menyadari akan proses berpikir mereka sendiri dan menimbulkan minat dalam belajar. Keaktifan peserta didik, kesadaran berpikir, serta minat dalam belajar akan sangat berperan besar dalam meningkatkan proses belajar mengajar dikelas yang akan berdampak pada penguasaan konsep dan hasil belajar peserta didik. 


\section{Hasil Belajar Kognitif Peserta Didik}

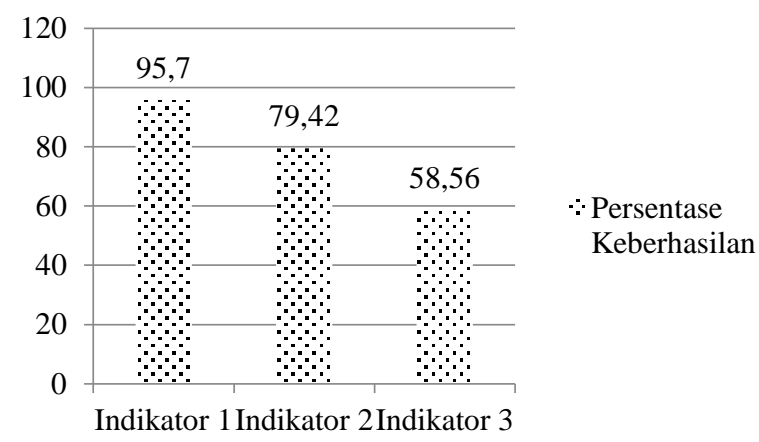

Gambar 3. Hasil belajar kognitif peserta didik siklus 1

Secara keseluruhan hasil belajar pada siklus I sudah cukup baik tetapi belum optimal. Rata-rata pencapaian untuk ketiga indikator peserta didik sebesar $77,68 \%$ dalam kategori baik, dengan masih terdapatnya indikator dalam kriteria kurang pada indikator 3 yaitu indikator menentukan oksidator dan reduktor dalam reaksi redoks. Ketuntasan belajar peserta didik pada siklus I jika dilihat berdasarkan Kriteria Ketuntasan Minimal SMA Negeri 11 Banjarmasin yaitu 70 secara klasikal penguasaan materi adalah sebesar $71,42 \%$ peserta didik belum memenuhi kriteria ketuntasan secara penguasaan materi karena masih kurang dari $75 \%$. Pembelajaran pada siklus I dirasakan belum optimal dapat dilihat dari hasil refleksi pada siklus I sehingga diperlukan perbaikan proses pembelajaran pada siklus II untuk lebih meningkatkan hasil belajar peserta didik pada materi reaksi reduksi dan oksidasi.

Berdasarkan tes evaluasi yang telah dilakukan pada akhir siklus I terdapat 1 indikator pembelajaran yang pencapaiannya hanya $58,56 \%$ dan termasuk dalam kategori kurang. Berdasarkan jawaban-jawaban peserta didik untuk soal-soal pada indikator ketiga ini peserta didik terlihat kesulitan untuk menentukan bilangan oksidasi unsur dalam senyawa atau ion sehingga peserta didik tidak dapat menyelesaikan soal yang berkaitan dengan oksidator dan reduktor ini dengan baik. Diperlukan ketelitian dan kesabaran untuk menghitung bilangan oksidasi pada suatu unsur dalam suatu senyawa ataupun dalam suatu reaksi redoks. Hal tersebut akan terlaksana dengan baik jika peserta didik lebih sering melakukan latihan.

Pada saat kegiatan pembelajaran berlangsung peserta didik telah mampu memahami konsep penentuan bilangan oksidasi ini dengan baik. Hanya saja saat dilakukan tes dengan soal-soal yang berbeda dan sedikit rumit mereka kurang teliti sehingga kebanyakan peserta didik keliru dalam menjawab. Hal ini berdampak secara langsung pada penilaian hasil belajarnya.

Masih terdapatnya peserta didik yang belum tuntas dalam siklus I sebanyak 3 orang disebabkan oleh kurang optimalnya pelaksanaan proses pembelajaran. Sebagaimana hasil observasi beberapa peserta didik yang tidak tuntas merupakan peserta didik yang keterlibatannya dalam pembelajaran di kelas tergolong kurang. Pada tes kognitif yang dilakukan pada siklus I ini skor terendah yang dicapai peserta didik adalah 60 dan skor tertinggi adalah 100. Hasil tes kognitif yang diperoleh oleh peserta didik tersebut disebabkan oleh kurang aktifnya peserta didik di kelas untuk mengeluarkan pendapat dan menjawab pertanyaan dari guru.

Berdasarkan hal terseut dapat terlihat bahwa pembejaran pada siklus I ini belum optimal, hal ini disebabkan oleh beberapa hal yaitu: 
(1) Guru belum terampil memberikan pertanyaan-pertanyaan penggali pada fase eksplorasi, sehingga peserta didi tidak mengalami proses berpikir yang optimal atau dapat dikatakan peserta didik tidak mengalami ketidakseimbangan kognitif yang diharapkan.

(2) Guru belum optimal dalam membimbing peserta didik yang terlihat pasif selama kegiatan pembelajaran. Misalnya pada fase penjelasan, terlihat peserta didik yang mengemukakan pendapat dan menjawab pertanyaan yang diberikan oleh guru adalah peserta didik yang pandai dan tidak bervariasi artinya cenderung hanya beberapa peserta didik yang sama menjawab pertanyaan guru. Atau dapat dikatakan guru belum mampu menentukan peserta didik yang menjawab pertanyaan dengan merata. Sebagaimana dengan penelitian dari Iktiarianti, Redjeki, \& Mulyani (2015) mengatakan bahawa pada fase ini keaktifan peserta didik masih didominasi hanya peserta didik yang berani meungkapkan pendapat dan maju kedepan kelas.

(3) Guru belum mampu mengelola peserta didik dengan baik misalnya dalam diskusi kelomok pada fase penerapan konsep, peserta didik yang berdiskusi dalam kelompok hanya beberapa orang saja sementara beberapa yang lain cenderung tidak terlibat dalam diskusi dan membuat suasana di kelas menjadi sedikit ribut sehingga tidak semua anggota kelompok dapat memahami materi yang diberikan guru dengan baik.

(4) Guru belum mampu memanfaatkan waktu yang tersedia dengan efisien.

Kekurangan yang terdapa pada siklus I inilah harus diperbaiki oleh guru pada kegiatan pembelajaran siklus II agar hasil belajar peserta didik mengalami peningkatan. Sebagaimana dijelaskan oleh Soebagio (Dasna, 2006) bahwa kekurangan penerapan model pembelajaran Learning Cycle yang harus diantisipasi diperkirakan adalah sebagai berikut : (1) Efektivitas pembelajaran rendah jika guru tidak menguasai materi dan langkah-langkah pembelajaran; (2) Menuntun kesungguhan dan kreativitas guru dalam merancang dan melaksanakan proses pembelajaran; (3) Memerlukan pengelolaan kelas yang lebih teencana dan terorganisasi; (4) Memerlukan waktu dan tenaga yang lebih banyak dalam menyusun rencana dan melaksanakan pembelajaran.

Perbaikan terhadap kekurangan yang terjadi pada siklus I mengakibatkan peningkatan terhadap aktivitas guru, aktivitas peserta didik dan kemampuan kognitif peserta didik. Pada pembelajaran siklus II diketahui bahwa guru telah mengefisienkan waktu sesuai dengan yang telah direncanakan. Pemberian perhatian yang dilakukan oleh guru terhadap peserta didik secara merata membuat peserta didik yang tampak pasif pada siklus I menjadi aktif pada siklus II dalam kegiatan tanya-jawab atau pada fase pendahuluan (engagement).

Tabel 1. Hasil ketuntasan belajar peserta didik pada tes siklus 1

\begin{tabular}{ccc}
\hline Nilai kognitif peserta didik & $\boldsymbol{\Sigma}$ peserta didik & peserta didik (\%) \\
\hline$<70$ & 10 & 28,57 \\
$\geq 70$ & 25 & 71,42 \\
\hline Jumlah total peserta didik & $\mathbf{3 5}$ & $\mathbf{1 0 0 , 0 0}$ \\
\hline
\end{tabular}




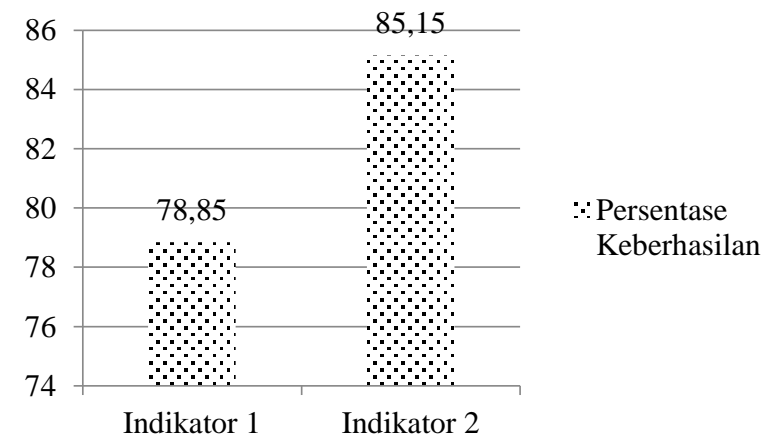

Gambar 4. Hasil belajar kognitif peserta didik siklus 2

Peningkatan kognitif tersebut dilihat dari hasil belajar paa siklus II meningkat dalam pencapaian indikator dan ketuntasan belajar. Perbaikan proses pembelajaran pada siklus II menjadikan indikator yang dicapai peserta didik dalam kriteria amat baik dan baik, dimana rata-rata pencapaian untuk kedua indikator peserta didik sebesar $81,99 \%$. Ketuntasan belajar peserta didik pada siklus II menurut Kriteria Ketuntasan Minimal SMA Negeri 11 Banjarmasin yaitu 70 adalah secara klasikan penguasaan materi sebesar $91,42 \%$ dimana terdapat 33 peserta didik yang tuntas dan 2 peserta didik yang nilainya masih dibatasan nilai KKM yaitu 70.

Terdapat 2 indikator pembelajaran yang diujikan dalam tes siklus II ini, dimana rata-rata penguasaan kedua indikator adalah $81,99 \%$ artinya penguasaan peserta didik termasuk dalam kriteria baik. Pada siklus II ini tidak ditemukan penguasaan indikator dalam kriteria kurang. Berdasarkan hasil tes hanya terdapat 2 peserta didik yang nilainya pas tuntas yaitu dengan skor 70. Secara keseluruhan kegiatan pembelajaran pada siklus II ini telah mendapatkan hasil yang maksimal.

Tabel 2. Hasil ketuntasan belajar peserta didik pada tes siklus 2

\begin{tabular}{ccc}
\hline Nilai kognitif peserta didik & $\boldsymbol{\Sigma}$ peserta didik & peserta didik $(\boldsymbol{\%})$ \\
\hline$<70$ & 3 & 8,57 \\
$\geq 70$ & 32 & 91,42 \\
\hline Jumlah total peserta didik & $\mathbf{3 5}$ & $\mathbf{1 0 0 , 0 0}$ \\
\hline
\end{tabular}

Respon peserta didik terhadap model pembelajaran learning cycle 5 Fase

Tabel. 3 hasil respon belajar peserta didik pada tes siklus 2

\begin{tabular}{cccc}
\hline \multirow{2}{*}{ Skor } & Kategori & $\sum_{\text {Peserta Didik }}$ & Persentase (\%) \\
\cline { 3 - 4 } & & 9 & 25,71 \\
$39-40$ & Sangat baik & 20 & 57,14 \\
$35-38$ & Baik & 6 & 17,14 \\
$24-34$ & Cukup baik & & \multicolumn{2}{c}{ Jumlah } \\
\hline
\end{tabular}

Berdasarkan hasil penilaian angket respon peserta didik terhadap penerapan model pembelajaran Learning Cycle 5 Fase dapat diketahui bahwa peserta didik merasa tertarikdengan model pembelajaran Learning Cycle 5 Fase. Dalam proses belajar mengajar dengan menggunakan model pembelajaran Learning Cycle 5 Fase siswa tetap diberi kesempatan untuk berinteraksi dengan peserta didik lain. Serta eserta didik merasa proses pembelajaran dengan model pembelajaran Learning Cycle 5 Fase dapat menumbuhkan keaktifannya dan menumbuhkan motivasinya untuk menjawab pertanyaan dan berdiskusi dengan anggota kelompoknya. 
Berdasarkan pembahasan diatas dapat dikatakan bahwa penerapan model pembelajaran Learning Cycle 5 Fase telah berhasil memperbaiki proses pembelajaran sehingga dapat meningkatkan hasil belajar dari siklus I dan siklus II pada materi reaksi reduksi dan oksidasi peserta didik kelas X MIPA 2 SMA Negeri 11 Banjarmasin serta memberikan respon yang positif terhadap proses pembelajaran yang dilaksanakan. Penelitian ini sejalan dengan penelitian dari Saputri, Medriati \& Rohadi (2018) yang menunjukkan bahwa pembelajaran dengan menggunakan model Learning Cycle 5 Fase dan Rejeki, Hasan \& Gani (2015), yang menunjukkan bahwa pembelajaran dengan menggunakan model Learning Cycle 5 Fase dapat meningkatkan aktivitas belajar, hasil belajar kognitif, dan keterampilan proses sains. Rejeki, Hasan \& Gani (2015), yang menunjukkan bahwa pembelajaran dengan menggunakan model Learning Cycle 5 Fase dapat meningatkan hasil belajar dan sikap peserta didik. Dan penelitian dari Iktiarianti, Redjeki, \& Mulyani (2015) penerapan model Learning Cycle 5 Fase dapat meningkatkan aktivitas dan prestasi belajar peserta didik.

\section{SIMPULAN}

Berdasarkan data hasil penelitian dan pembahasan dapat disimpulkan bahwa penerapan model pembelajaran Learning Cycle 5 fase dapat meningkatkan hasil belajar siswa pada pembelajaran materi reaksi reduksi dan oksidasi. Selain itu, siswa memberikan respon positif terhadap penerapan model pembelajaran Learning Cycle 5 fase pada pembelajaran materi reaksi reduksi dan oksidasi.

\section{DAFTAR RUJUKAN}

Arikunto, S. 2007. Dasar-dasar Evaluasi Pendidikan. Jakarta :Bumi aksara.

Arikunto, S., Suhardjono, \& Supardi. 2009. Penelitian Tindakan Kelas. Jakarta: Bumi Aksara.

Saputri, A. D., Medriati, R., \& Rohadi, N. (2018). Penerapan model learning cycle untuk meningkatkan hasil belajar kognitif dan keterampilan proses sains pada materi usaha dan energi di kelas X MIA 3 MAN 2 Kota Bengkulu. Jurnal Kumparan Fisika, 1(1 April), 7-12.

Aqib, Z. 2019. Penelitian Tindakan Kelas. Yrama Widya. Bandung

Dasna, I. W. 2006. Model Siklus Belajar (Learning Cycle). Malang : FMIPA Universitas Negeri Malang

Dimiyati \& Mudjiyono. 2015. Belajar dan pembelajaran. Rineka Cipta. Jakarta

Depdiknas. 2004. Keputusan Kepala Dinas Pendidikan Propinsi Kalimantan Selatan tentang Pedoman penyelenggaraan Ujian Akhir Nasional bagi Sekolah Madrasah Tahun Pelajaran 2003/2004. Pemerintah Propinsi Kalimantan Selatan.

Fajaroh, F., \& Dasna, I. W. (2003). Penggunaan Model Pembelajaran Learning Cycle Untuk Meningkatkan Motivasi Belajar Dan Hasil Belajar Kimia Zat Aditif Dalam Bahan Makanan Pada Siswa Kelas Ii Smu Negeri 1 TumpangMalang. Jurnal Pendidikan dan Pembelajaran, 11(2), 112-122.

Ikhtiarianti, M. D., Redjeki, T., \& Mulyani, S. (2015). Penerapan Model Pembelajaran Siklus Belajar 5e (Learning Cycle 5e) Berbantuan Tutor Sebaya (Peer Tutoring) Untuk Meningkatkan Aktivitas Dan Prestasi Belajar Siswa Pada Materi Larutan Penyangga Kelas XI Mia 1 SMA Negeri Colomadu Tahun Pelajaran 2014/2015. Jurnal Pendidikan Kimia, 4(4), 173179.

Rejeki, D. P., Hasan, M., \& Gani, A. (2015). Penerapan Model Pembelajaran Learning Cycle 5E Pada Materi Kelarutan dan Hasil Kali Kelarutan Untuk 
Meningkatkan Hasil Belajar dan Sikap Peserta Didik SMAN 1 Krueng Barona Jaya. Jurnal Pendidikan Sains Indonesia (Indonesian Journal of Science Education), 3(1), 19-26.

Rusman. 2014. Model-Model Pembelajaran Mengembangkan Profesionalisme Guru. Grafindo. Jakarta

Sudijono, A. 2009. Pengantar Statistik Pendidikan. Jakarta :PT. Raja Grafindo Persada.

Susanto, Ahmad. 2014. Teori Belajar dan Pembelajaran di Sekolah Dasar. Kencana. Jakarta

Suyono dan Hariyanto. 2011. Belajar dan Pembelajaran. Bandung : PT. Remaja Rosdakarya.

Tek, O. E., Baharom, S., \& Saad, M. I. M. (2011). Self-Regulated Learning: Gender Differences in Motivation and Learning Strategies Amongst Malaysian Science Students (92-104). Jurnal Pendidikan Bitara UPSI, 4(1), 92-104. 